\title{
NEW TRAMP ANT SPECIES FOR TURKEY: Tetramorium lanuginosum Mayr (HYMENOPTERA: FORMICIDAE)
}

\author{
Celal KARAMAN*, Kadri KIRAN \\ Trakya University, Faculty of Science, Department of Biology, Balkan Campus, 22030, Edirne, TURKEY \\ *Corresponding author: e-mail: celalkaraman@trakya.edu.tr
}

Cite this article as:

Karaman C. \& Kiran K. 2018. New Tramp Ant Species for Turkey: Tetramorium lanuginosum Mayr (Hymenoptera: Formicidae). Trakya Univ J Nat Sci, 19(1): 51-54, DOI: 10.23902/trkjnat.346537

Received: 26 September 2017, Accepted: 11 January 2018, Online First: 17 January 2018, Published: 15 April 2018

\begin{abstract}
Human activities such as tourism, developed transportation and increased trade lead to the introduction of faunal elements into non-native habitats and consequently affect native fauna. These introduced species are called as non-native, exotic, invasive or tramp species. Here we record the well-known tramp species Tetramorium lanuginosum Mayr, for the first time from Turkey (Antalya-Alanya), and present first locality records for Paratrechina longicornis (Latreille) from AntalyaAlanya and Adana. Thus, the number of tramp ant species of Turkey is increased to 19.
\end{abstract}

Key words: Tramp species, new record, Northeastern Mediterranean, Antalya-Alanya.

Özet: Turizm, gelişmiş ulaşım ve artan ticaret gibi insan faaliyetleri faunal elemanların dağılım alanları dışındaki habitatlara taşınmasına neden olmakta ve dolayısıyla yerli faunayı etkilemektedir. Bu faaliyetlerle taşınan organizmalar yerli olmayan, egzotik, istilacı veya tramp türler olarak adlandırılır. Bu çalışmada, çok iyi bilinen tramp karınca türü olan Tetramorium lanuginosum Mayr'u Türkiye'den (Antalya-Alanya) ilk defa kayıt edilmekte ve Paratrechina longicornis (Latreille)'e ait ilk lokalite kayıtları ise Antalya-Alanya ve Adana'dan verilmektedir. Böylece, Türkiye'de tramp karınca tür sayısı 19'a yükselmiştir.

\section{Introduction}

The increasing rate of human activities (e.g. trade, tourism, developing projects, globalization, import and export etc.) cause the spread of faunal elements out of their native ecosystems (Chown et al. 1998, IUCN 2000, Clavero \& Garcia-Berthou 2005). The transferred species are called "non-native", "alien", "exotic", "invasive", and "tramp" species (McGlynn 1999, Ivanov 2016). Mcglynn (1999) recorded 146 ant species belonging to 48 genera within 7 subfamilies, while AntWeb (2017) listed more than 200 ant species belonging to 65 genera within 18 subfamilies as tramp, but the real number is most probably higher (Miravete et al. 2014).

Turkey is an important destination for tourism (Tursab 2016), with more than 35 million tourists who visited the country each year in the last decade. The geographic position of Turkey as a peninsula and the increased internal and external trade activities by shipping resulted in the introduction of non-native ant species to the country. For instance, Anoplolepis gracilipes (F. Smith), Camponotus compressus (Fabricius), C. maculatus (Fabricius), Hypoponera punctatissima (Roger), Linepithema humile (Mayr), Solenopsis geminata (Fabricius), Paratrechina

longicornis (Latreille), and Tetramorium bicarinatum (Nylander) have recently been recorded from Turkey as tramp species (Borowiec 2014), but without their distribution localities. According to the records of Borowiec (2014) and AntWeb (2017) the current number of tramp species known from Turkey is 32 .

Here we present a new tramp ant species $T$. lanuginosum Mayr from Antalya-Turkey and give the first locality based records of $P$. longicornis (Latreille) from Antalya and Adana.

\section{Materials and Methods}

\section{Tetramorium lanuginosum Mayr}

Turkey, Antalya-Alanya $\left(36^{\circ} 32^{\prime} 41^{\prime \prime} \mathrm{N}, 31^{\circ} 59^{\prime} 59^{\prime \prime}\right.$

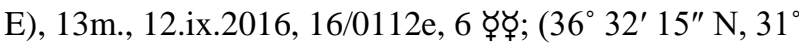
59' 53" E), 17m., 12.ix.2016, 16/0115c, 3 ఛఢ, leg. C. Karaman.

\section{Paratrechina longicornis (Latreille)}

Turkey, Antalya-Alanya ( $36^{\circ} 32^{\prime} 00^{\prime \prime} \mathrm{N}, 31^{\circ} 59^{\prime} 25^{\prime \prime}$ E), 221m., 12.ix.2016, 16/0113a, 20 ఫॄ, leg. C. Karaman; 
Adana $\left(36^{\circ} 58^{\prime} \mathrm{N}, 35^{\circ} 20^{\prime} \mathrm{E}\right), 30 \mathrm{~m} .$, 01.vii.2016, 16/0104b, 4 ซ్, S. Yildı.

The specimens of both species were collected by an aspirator. Digital images were prepared using Nikon D800E DSLR camera with $3.2 \mathrm{x}$ and $8 \mathrm{x}$ microscope objectives and Combine-Z (2008) free software. The images were cropped with Adobe Photoshop CS2.

Antalya-Alanya and Adana is characterized by a Mediterranean type climate with hot and dry summers and mild and wet winters. The average annual temperature and precipitation values are $18.7^{\circ} \mathrm{C}$ and $1087 \mathrm{~mm}$ for Antalya-Alanya and $19.3^{\circ} \mathrm{C}$ and $679 \mathrm{~mm}$ for Adana, respectively. Moreover, the average temperature of winter season of these two provinces never fall below $10^{\circ} \mathrm{C}$ (Climate-data.org).

\section{Results}

\section{Tetramorium lanuginosum Mayr (Fig. 1)}

Diagnosis: Tetramorium lanuginosum with $T$. bicarinatum are among the few Turkish ants with antennal scrobe. Tetramorium lanuginosum can be readily discriminated from T. bicarinatum and from other Turkish Tetramorium species by the long and profuse bifid pilosity.

\section{Paratrechina longicornis (Latreille) (Fig. 2)}

Diagnosis: Paratrechina longicornis is differentiated from all other species of the genus by 5 toothed mandibles, the stiff and blunt hairs and the bare antennal scape.

\section{Discussion}

The tramp ant species have been known since more than one century. Forel (1911) recorded fifteen ant species spread by human activities in 1911 and Wetterer (2010) mentioned that eight of them [Anoplolepis gracilipes, Linepithema humile, Trichomyrmex. destructor, Monomorium pharaonis, Paratrechina longicornis, Pheidole megacephala, Solenopsis geminata, and Tapinoma melanocephalum (Fabricius)] became "serious pest species" worldwide.

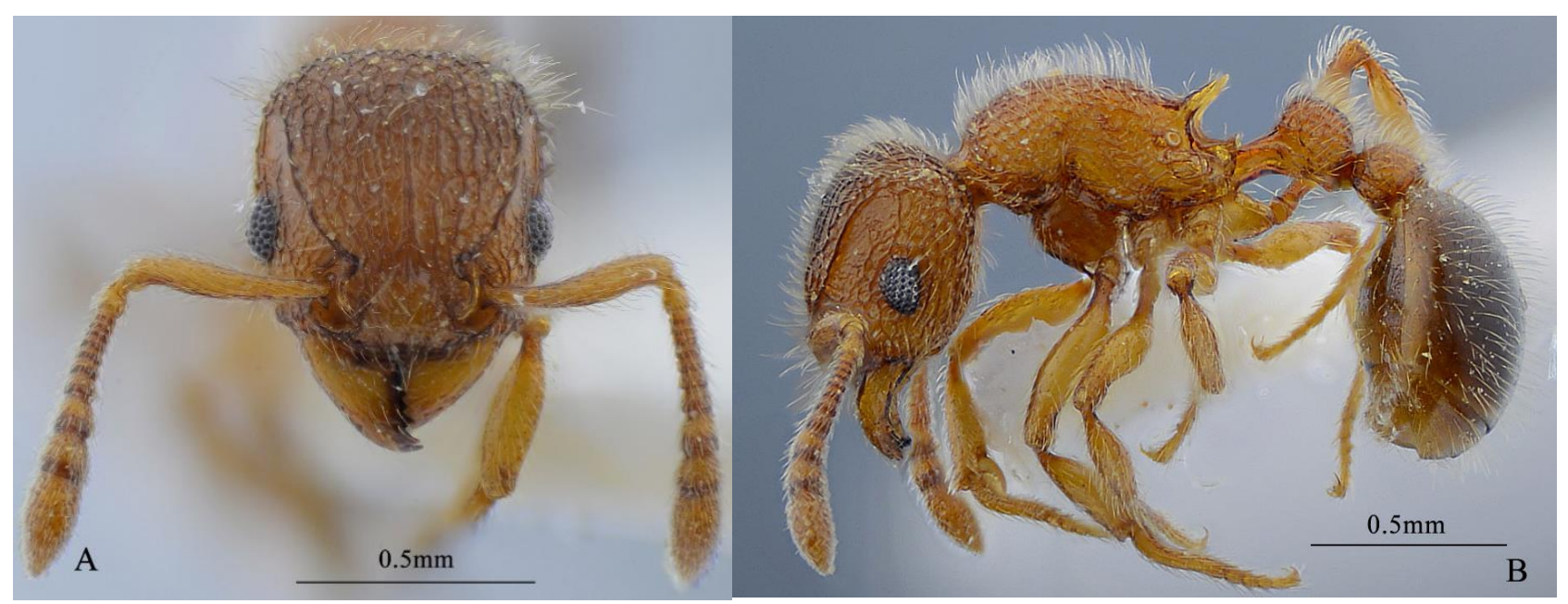

Fig. 1. Tetramorium lanuginosum: A- Head in full-face view, B- Body in profile.

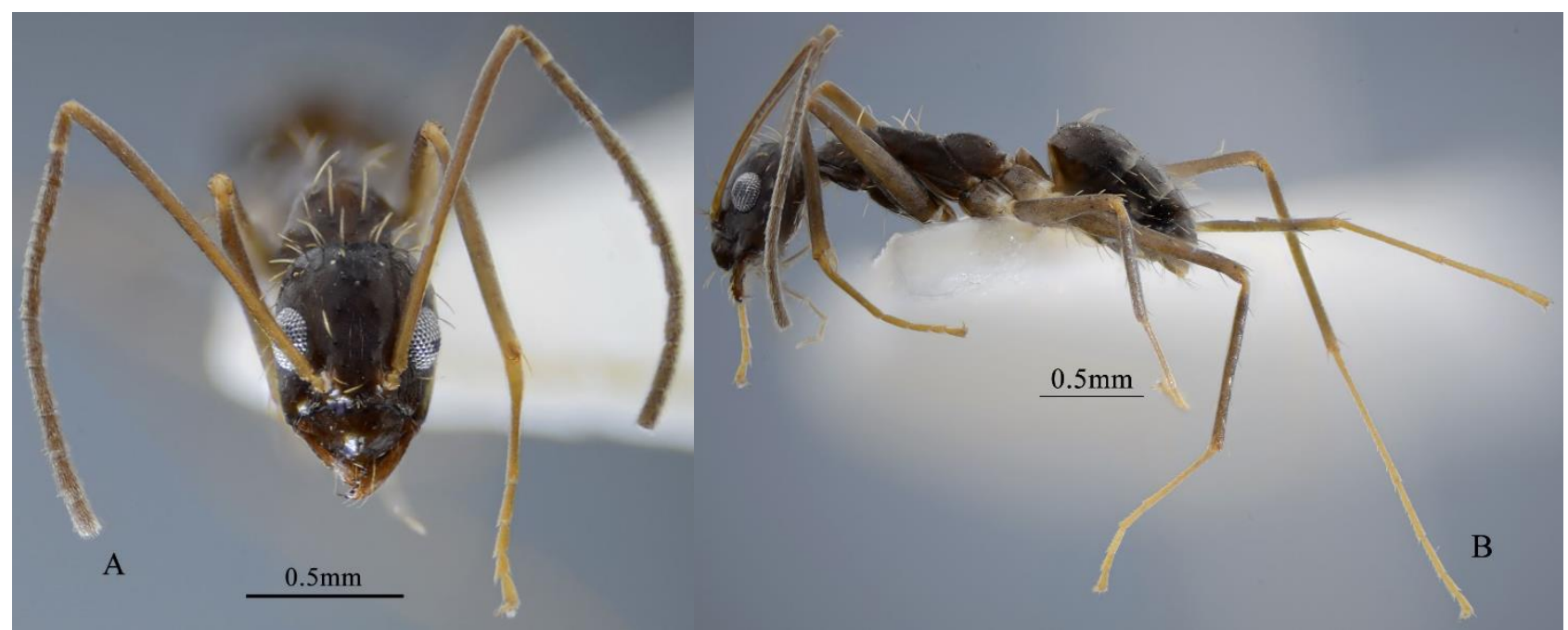

Fig. 2. Paratrechina longicornis: A- Head in full-face view, B- Body in profile. 
Four of these serious pest ant species (A. gracilipes, $L$. humile, S. geminata and $P$. longicornis) were reported from Turkey by Borowiec (2014) without exact locality records. Monomorium pharonis and $P$. megacephala were recorded by different researchers from different localities in Turkey. The other problematic species, T. destructor, is a native ant species for Turkish ant fauna and only one of them (Tapinoma melanocephalum) has not been recorded so far from Turkey.

The records available from Borowiec (2014) and AntWeb (2017) point out presence of at least 32 tramp ant species from Turkey (Table 1). However, 14 ant species (Table 1; written as red) from this list are native to Turkey because their native distribution range comprise Turkey. As a result, the exact and real tramp ant species number of Turkey needs to be revised as 18 (Table 1; written as black).

Tetramorium lanuginosum is widely distributed across tropical and subtropical regions with several records in countries in Western Palearctic (Egypt, England, Israel, Lebanon, Libya, Malta, Netherlands, Spain, Tunisia and Saudi Arabia). We recorded $T$. lanuginosum from two different urban habitats, pavements of historical bazaar and a coastal road in Alanya (Figure 3A). These findings let us to conclude without doubt that T. lanuginosum is settle to Alanya and became a putative permanent tramp species.
Paratrechina longicornis has been recorded in the Western Palearctic Region from Algeria, Azores, Balearic Islands, Belgium, Canary Islands, Czech Republic, Denmark, Egypt, England, Estonia, France, Netherlands, Germany, Gibraltar, Greece, Iran, Iraq, Israel, Italy, Lebanon, Libya, Malta, Morocco, Saudi Arabia, Spain, Sweden, Switzerland, Syria and United Arab Emirates. We recorded $P$. longicornis in a semi-rural area of Alanya castle (Figure 3B). The workers were collected from Pinus brutia Tenore trunk where they were most probably feeding with aphid honeydew. The Adana record of the species was also from semi-rural area but no information on its biology is available.

Boer \& Vierbergen (2008) divided the tramp ant species into 4 groups as intercepted tramps, temporary tramps, local tramps and permanent tramps according to their existence in a country. According to Boer and Vierbergen's classification, local tramps are non-native ant species moved away from the entry medium and dispersed to settle a temporary population. Permanent tramps are also non-native ant species who settled permanent populations and spread different locations. We, therefore, can categorize T. lanuginosum as a local tramp and $P$. longicornis as a permanent tramp species. Many tropical and subtropical ant species will become tramp ant species in the future due to global warming (Boer \& Vierbergen 2008).

Table 1. Tramp ant species of Turkey according to the list in AntWeb (regular: native ant species; bold: tramp ant species).

\begin{tabular}{|c|c|}
\hline SUBFAMILY DOLICHODERINAE & SUBFAMILY MYRMICIANE \\
\hline 1. Dolichoderus quadripunctatus (Linnaeus) & 17. Cardiocondyla emeryi Forel \\
\hline 2. Linepithema humile (Mayr) & 18. Cardiocondyla mauritanica Forel \\
\hline SUBFAMILY FORMICINAE & 19. Monomorium monomorium Bolton \\
\hline 3. Anoplolepis gracilipes (F. Smith) & 20. Monomorium pharaonis (Linnaeus) \\
\hline 4. Camponotus compressus (Fabricius) & 21. Monomorium subopacum (F. Smith) \\
\hline 5. Camponotus maculatus (Fabricius) & 22. Myrmica rubra (Linnaeus) \\
\hline 6. Camponotus vagus (Scopoli) & 23. Myrmica specioides Bondroit \\
\hline 7. Camponotus variegatus (F. Smith) & 24. Pheidole indica Mayr \\
\hline 8. Lasius alienus (Foerster) & 25. Pheidole megacephala (Fabricius) \\
\hline 9. Lasius fuliginosus (Latreille) & 26. Strumigenys membranifera Emery \\
\hline 10. Lasius neglectus Van Loon, Boomsma \& Andrásfalvy & 27. Solenopsis geminata (Fabricius) \\
\hline 11. Lepisiota frauenfeldi (Mayr) & 28. Tetramorium bicarinatum (Nylander) \\
\hline 12. Nylanderia jaegerskioeldi Mayr & 29. Tetramorium cf. caespitum (Linnaeus) \\
\hline 13. Nylanderia vividula (Nylander) & 30. Trichomyrmex destructor (Jerdon) \\
\hline 14. Paratrechina longicornis (Latreille) & SUBFAMILY PONERINAE \\
\hline 15. Plagiolepis pygmaea (Latreille) & 31. Hypoponera eduardi (Forel) \\
\hline SUBFAMILY MYRMICIANE & 32. Hypoponera punctatissima (Roger) \\
\hline 16. Crematogaster sordidula (Nylander) & \\
\hline
\end{tabular}




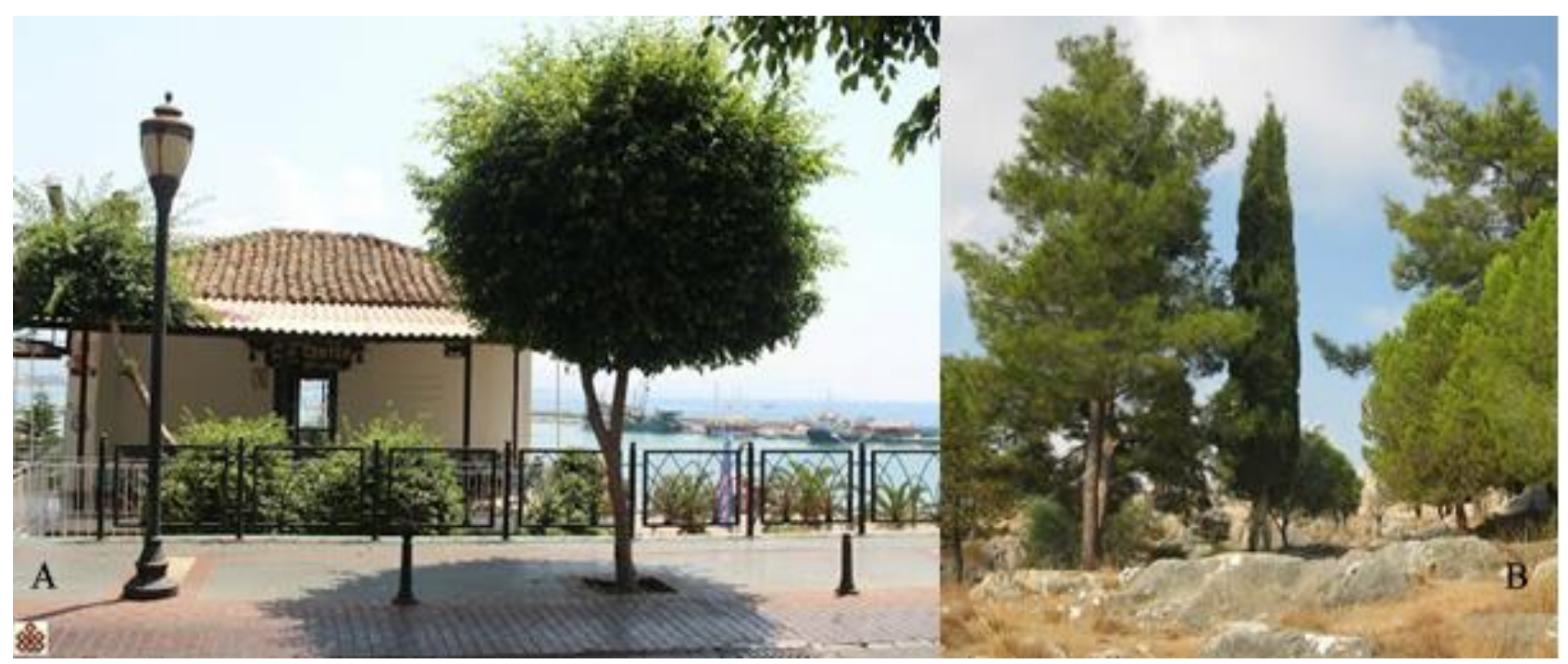

Fig. 3. Microhabitat of the species: A- T. lanuginosum; B- P. longicornis.

In conclusion, the current and exact number of tramp ant species in Turkey, after the exclusion of 14 species, all which were regarded as to have a native distribution in Turkey, from the list one can deduce considering the data in Borowiec (2014) and AntWeb (2017) (see Table 1 ), is increased to 19 by the present record of $T$. lanuginosum. We are expecting that this number will increase in the future with more collecting efforts in urban and semi-rural areas especially in southern parts of Turkey.

\section{References}

1. AntWeb, 2017. Available from: https://www.antweb.org/taxonomicPage.do?rank=species\& project=introducedants\&images=true. (Date accessed: September 2017).

2. Boer, P. \& Vierbergen, B. 2008. Exotic ants in The Netherlands (Hymenoptera: Formicidae). Entomologische Berichten, 68: 121-129.

3. Borowiec, L. 2014. Catalogue of ants of Europe, the Mediterranean Basin and adjacent regions (Hymenoptera: Formicidae). Genus, 25(1-2): 1-340.

4. Chown, S.L., Gremmen, N.J.M. \& Gaston, K.J. 1998. Ecological biogeography of Southern Ocean islands: species-area relationships, human impacts, and conservation. The American Naturalist, 152: 562-575.

5. Clavero, M. \& Garcia-Berthou, E. 2005. Invasive species are a leading cause of animal extinctions. Trends in Ecology \& Evolution, 20: 110.

6. Climate-data.org. Climate data for cities worldwide. http://en.climate-data.org. (Date accessed: September 2017).

7. Forel, A. 1911. Aperçu sur la distribution géographique et la phylogénie des fourmis, 81-100. Memoires I ${ }^{\text {er }}$ Congres International d'Entomologie, Bruxelles, Belgium.

\section{Acknowledgement}

We are thankful to Saniye Yildiz for collecting $P$. longicornis specimens from Adana. This study was represented as a poster presentation in $7^{\text {th }}$ Central European Workshop of Myrmecology, in Krakow-Poland.

Editor-in-Chief note: Authors Celal Karaman and Kadri Kiran are a member of Editorial Board of Trakya University Journal of Natural Sciences. However, they weren't involved in the decision process during manuscript evaluation.

8. IUCN, 2000. Guidelines for the prevention of biodiversity loss due to biological invasion. Gland: IUCN -The World Conservation Union; $21 \mathrm{pp}$.

9. Ivanov, K. 2016. Exotic ants (Hymenoptera, Formicidae) of Ohio. Journal of Hymenoptera Research, 51: 203-226.

10. McGlynn, T.P. 1999. The worldwide transfer of ants: geographical distribution and ecological invasions. Journal of Biogeography, 26: 535-548.

11. Miravete, V., Roura-Pascal, N., Dunn, R.R. \& Gómez, C. 2014. How many and which ant species are being accidentally moved around the world? Biology Letters, 10: 20140518.

12. Tursab, 2016. Turizm verileri. http://www.tursab.org.tr/tr/turizm-verileri/istatistikler/turistsayisi-ve-turizm-geliri/2003-gelirsayi-ve-ortalamaharcama_68.html. (Date accessed: March 2017).

13. Wetterer, J.K. 2010. Worldwide spread of the wooly ant, Tetramorium lanuginosum (Hymenoptera: Formicidae). Myrmecological News, 13: 81-88. 
